\title{
Analysis of the impact of selected hospital practices on exclusive breastfeeding
}

\section{Analiza wpływu wybranych praktyk szpitalnych na wyłączne karmienie piersią}

\author{
Dorota Ćwiek ${ }^{1}$, Katarzyna Przeradzka², Marta Stanisz ${ }^{3}$, Agnieszka Kardziejonek², Dorota Fryc ${ }^{1}$, \\ Katarzyna Szymoniak ${ }^{1}$ \\ 1 Pomorski Uniwersytet Medyczny w Szczecinie, Samodzielna Pracownia Umiejętności Położniczych, ul. Żołnierska 48, 71-246 Szczecin \\ ${ }^{2}$ Pomorski Uniwersytet Medyczny w Szczecinie, Klinika Perinatologii, Położnictwa i Ginekologii, ul. Siedlecka 2, 72-100 Police \\ ${ }^{3}$ Pomorski Uniwersytet Medyczny w Szczecinie, Studenckie Koło Naukowe im. S. Leszczyńskiej przy Samodzielnej Pracowni Umiejętności Położniczych, \\ ul. Zołnierska 48, 71-210 Szczecin \\ $\triangle$ spppol@pum.edu.pl
}

\begin{abstract}
Introduction: Breastfeeding is the optimal method of feeding children during the first period of their life. The correct management of lactation is essential for proper breastfeeding initiation which would be continued long enough. Many factors have a huge impact on lactation, among others mode of delivery, parturition, hospital procedures and practices, such as suctioning the airway, 'skin to skin' contact, feeding the baby, and the competent support of the staff.

The aim of the study was to analyze the impact of selected procedures related to childbirth and post-natal care, as well as hospital practices on lactation.

Materials and methods: The study involved 145 women who gave birth in the Department of Foetal Medicine and Gynaecology Pomeranian Medical University in Szczecin located in Police, West Pomeranian Province in Poland. The research
\end{abstract}

was carried out by a diagnostic survey with a self-authorship questionnaire.

Conclusions: 1 . Some hospital practices, such as suctioning the airway, short 'skin to skin' contact after cesarean delivery, and complementary feeding of a newborn baby with a bottle had negative impact on maintaining lactation. 2. Complementary feeding of an infant with a bottle was a frequent hospital practice. As the procedure has an adverse impact on lactation, breastfeeding should be replaced by complementary feeding in an alternative way only in justified cases. 3. Most of the patients who obtained support during lactation were breastfeeding exclusively. Competent assistance in initiating and maintaining lactation is the responsibility of the medical personnel, thus there is a necessity for their permanent development, and a constant need to modify hospital practices to ones that affect lactation favourably. Keywords: lactation; breastfeeding; hospital procedures.

\begin{abstract}
ABSTRAKT
Wstęp: Karmienie piersią jest optymalnym sposobem żywienia dzieci w pierwszym okresie ich życia. Prawidłowe postępowanie w laktacji jest podstawą właściwego jej rozpoczęcia oraz skutecznego karmienia, które będzie odpowiednio długo kontynuowane. Ogromny wpływ na proces laktacji ma wiele czynników, m.in. rodzaj porodu, przebieg porodu, procedury i praktyki szpitalne takie jak odśluzowanie, kontakt skóra do skóry, dokarmianie dziecka, kompetentna pomoc personelu.

Celem pracy była analiza wpływu wybranych procedur związanych z porodem i opieką po porodzie oraz praktyk szpitalnych na proces laktacji.

Materiały i metody: Badaniem objęto 145 kobiet, które urodziły dziecko w Klinice Medycyny Matczyno-Płodowej i Ginekologii Pomorskiego Uniwersytetu Medycznego w Szczecinie mieszczącej się w Policach, w województwie zachodniopomorskim.
\end{abstract}

Badania przeprowadzono metodą sondażu diagnostycznego, za pomocą kwestionariusza ankiety własnego autorstwa. Wnioski: 1. Niektóre praktyki szpitalne, takie jak odśluzowanie, krótki kontakt skóra do skóry po cięciu cesarskim i dokarmianie noworodków za pomocą butelki, wpływały negatywnie na zachowanie laktacji. 2. Dokarmianie noworodków za pomocą butelki stanowiło częstą praktykę szpitalną. Jako procedura wpływająca negatywnie na laktację, powinna być zastąpiona dokarmianiem w sposób alternatywny tyko w uzasadnionych przypadkach. 3. Większość pacjentek, które otrzymały pomoc w czasie laktacji, karmiły noworodka wyłącznie piersią. Kompetentna pomoc w rozpoczęciu i utrzymaniu laktacji jest obowiązkiem personelu medycznego, dlatego istnieje konieczność stałego doskonalenia oraz ciągła potrzeba modyfikacji praktyk szpitalnych korzystnie wpływających na laktację.

Słowa kluczowe: laktacja; karmienie piersią; procedury szpitalne.

is essential for proper initiation and effective breastfeeding which will be continued long enough [1]. Many factors have a huge impact on the lactation process, e.g. mode of delivery, parturition, hospital procedures and practices, such as
Breastfeeding is the optimal method of infant feeding during the first period of his life. The correct management of lactation 
suctioning the airway, 'skin to skin' contact, feeding the infant, and the competent support of the staff. Reducing or eliminating adversely affecting procedures, and the implementation of procedures positively influencing lactation should be basic treatment for medical personnel.

The aim of the study was to analyze the impact of selected procedures related to childbirth and post-natal care, as well as hospital practices on lactation.

\section{MALERIALS AND METHODS}

The study involved 145 women who gave birth in the Department of Foetal Medicine and Gynaecology Pomeranian Medical University in Szczecin located in Police, West Pomeranian Province in Poland. The survey was carried out from April 2014 to October 2014. The research was carried out by a diagnostic survey with a questionnaire of our own authorship. The collected material was analyzed statistically using the $\chi^{2}$ test.

\section{RESULTS}

The study comprised 145 women aged 18-45 years (mean age $=30.6$ ). Most patients surveyed were aged $26-30$ years and 31-35 years (36.5\% each). The second group consisted of women aged over 36 years (13.8\%). 13.1\% of patients were in the age group up to 25 years. Among the women surveyed $28.3 \%$ were unmarried, while $71.7 \%$ were married. Most of the respondents claimed to have had higher education (66.9\%), while patients with secondary or primary/vocational education amounted to $22.1 \%$ and $11.0 \%$, respectively. As many as $57.9 \%$ of the women surveyed indicated a big city as their

TABLE 1. Characteristics of the study group

\begin{tabular}{lcc}
\multicolumn{1}{c}{$\begin{array}{c}\text { The age structure of } \\
\text { respondents }\end{array}$} & $\mathbf{n = 1 4 5}$ & $\%$ \\
\hline Up to 25 years old & 19 & 13.1 \\
\hline $26-30$ years old & 53 & 36.5 \\
\hline $31-35$ years old & 53 & 36.5 \\
\hline Over 36 years old & 20 & 13.8 \\
\hline Marital status & $\mathbf{n = 1 4 5}$ & $\%$ \\
\hline Single & 41 & 28.3 \\
\hline Married & 104 & 71.7 \\
\hline Education & $\mathbf{n = 1 4 5}$ & $\%$ \\
\hline Primary/Vocational & 16 & 11.0 \\
\hline Secondary & 32 & 22.1 \\
\hline Higher & 97 & 66.9 \\
\hline Place of residence & $\mathbf{n = 1 4 5}$ & $\%$ \\
\hline A village & 19 & 13.1 \\
\hline A small town & $\mathbf{4 2}$ & 29.0 \\
\hline A big city & 84 & 57.9 \\
\hline Type of birth & $\mathbf{n = 1 4 5}$ & $\%$ \\
\hline Vaginal & 69 & \\
\hline Caesarean section & 76.4 \\
\hline
\end{tabular}

place of residence, then a small town $29.0 \%$, and a village $13.1 \%$. Most of the surveyed women gave birth by caesarean section (52.4\%), but women giving birth in a natural way were a little less $-47.6 \%$. The data are summarized in Table 1.

Most of the mothers whose infants did not have suctioning of the airway performed breastfed their babies (53.8\%). Mothers whose infants had suctioning of the airway performed breastfed less frequently (43.0\%), but there was no statistical significance (Tab. 2).

TABLE 2. Maintenance of feeding continuity in relation to the suctioning of the airway procedure

\begin{tabular}{|c|c|c|c|c|c|c|}
\hline \multirow{3}{*}{$\begin{array}{c}\text { Maintenance of } \\
\text { feeding continuity }\end{array}$} & \multicolumn{6}{|c|}{ After birth suctioning the newborn's airway } \\
\hline & \multicolumn{2}{|c|}{ yes } & \multicolumn{2}{|c|}{ no } & \multicolumn{2}{|c|}{ I do not know } \\
\hline & n & $\%$ & $\mathrm{n}$ & $\%$ & $\mathrm{n}$ & $\%$ \\
\hline $\begin{array}{l}\text { Yes, I still breastfeed } \\
\text { exclusively }\end{array}$ & 34 & 43.0 & 7 & 53.8 & 29 & 54.7 \\
\hline $\begin{array}{l}\text { Partly, } \\
\text { I had to introduce } \\
\text { milk formula }\end{array}$ & 41 & 51.9 & 5 & 38.5 & 22 & 41.5 \\
\hline $\begin{array}{l}\text { No, since a problem } \\
\text { appeared my baby } \\
\text { has been fed with } \\
\text { milk formula }\end{array}$ & 4 & 5.1 & 1 & 7.7 & 2 & 3.8 \\
\hline Total & 79 & 100.0 & 13 & 100.0 & 53 & 100.0 \\
\hline
\end{tabular}

Continuity of breastfeeding significantly depended on method of delivery. After vaginal delivery women mostly breast-fed their newborns exclusively (62.3\%). In the case of births by caesarean section infants were breast-fed significantly less often (35.5\%) - Table 3. This can result from shorter 'skin to skin' contact or cessation because of an infant's health condition.

Continuity of breastfeeding significantly depended on the method of complementary feeding. The most common method of complementary feeding in newborn babies was a bottle. Women who additionally bottle-fed their babies only partially breastfed (72.1\%). The infants were still given complementary foods (Tab. 4).

The impact of frequency of attaching an infant at the breast to maintain the continuity of feeding was noted, although the relationship is not statistically significant. Women who attached their newborns at the breast every 2-3 hours and on demand often breastfed exclusively (Tab. 5).

Such feeding problems as lack of food, little food, the impression that the baby was hungry, and additionally nourishing the baby had a significant impact on the continuity of breastfeeding. Patients who had little food or lack of it, had the impression that the baby was hungry and provided additional nourishment to newborns, and only partially sustained breast-feeding (Tab. 6).

Most of the difficulties that occurred in patients while breastfeeding had no significant effect on problems with feeding continuity. No statistically significant relationship between attachment difficulties and feeding continuity was noted (Tab. 7). 
TABLE 3. Maintenance of feeding continuity in relation to the method of delivery

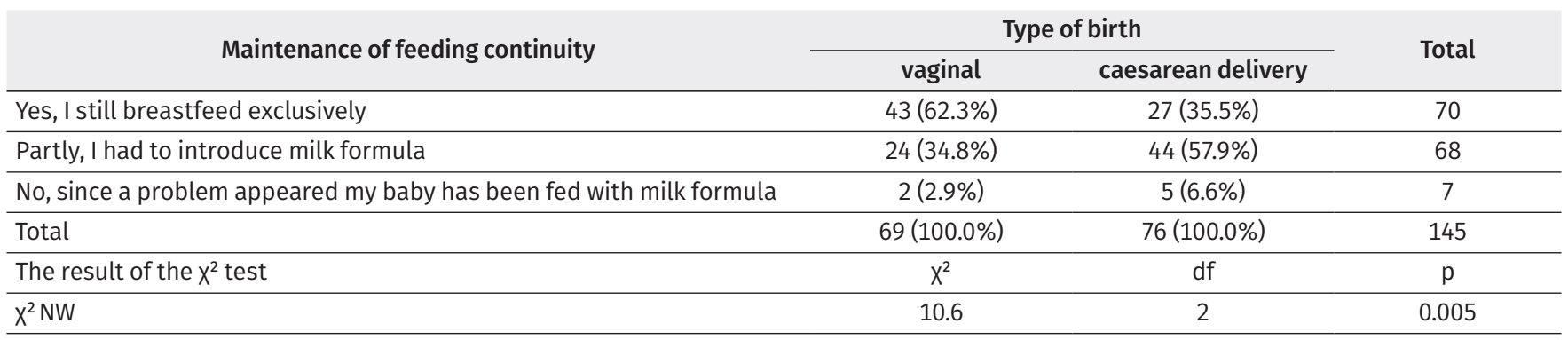

TABLE 4. Maintenance of feeding continuity in relation to complementary feeding method

\begin{tabular}{|c|c|c|c|c|}
\hline \multirow{2}{*}{ Maintenance of feeding continuity } & \multicolumn{2}{|c|}{ The method of complementary feeding } & \multirow{2}{*}{ Not applicable } & \multirow{2}{*}{ Total } \\
\hline & bottle & probe & & \\
\hline Yes, I still breastfeed exclusively & $19(20.4 \%)$ & $1(100.0 \%)$ & $50(98.0 \%)$ & 70 \\
\hline No, since there is a problem my baby is fed with milk formula & $7(7.5 \%)$ & $0(0.0 \%)$ & $0(0.0 \%)$ & 7 \\
\hline Total & $93(100.0 \%)$ & $1(100.0 \%)$ & $51(100.0 \%)$ & 145 \\
\hline The $x^{2}$ test result & $x^{2}$ & $\mathrm{df}$ & $\mathrm{p}$ & \\
\hline$X^{2} \mathrm{NW}$ & 97.0 & 4 & 0.000 & \\
\hline
\end{tabular}

TABLE 5. Maintenance of feeding continuity in relation to the frequency of infant attachment at the breast

\begin{tabular}{|c|c|c|c|c|c|}
\hline \multirow[b]{2}{*}{ Maintenance of feeding continuity } & \multicolumn{4}{|c|}{ Frequency of attachment at the breast } & \multirow[b]{2}{*}{ Tota } \\
\hline & $\begin{array}{l}\text { more than } \\
\text { every } 2 \text { hours }\end{array}$ & $\begin{array}{c}\text { every } \\
2-3 \text { hours }\end{array}$ & $\begin{array}{l}\text { less often than } \\
\text { every } 3 \text { hours }\end{array}$ & $\begin{array}{l}\text { on infant's } \\
\text { demand }\end{array}$ & \\
\hline Yes, I still breastfeed exclusively & $11(44.0 \%)$ & $34(49.3 \%)$ & $1(14.3 \%)$ & $24(54.6 \%)$ & 70 \\
\hline Partly, I had to introduce milk formula & $12(48.0 \%)$ & $33(47.8 \%)$ & $5(71.4 \%)$ & $18(40.9 \%)$ & 68 \\
\hline No, since there is a problem my baby is fed with milk formula & $2(8.0 \%)$ & $2(2.9 \%)$ & $1(14.3 \%)$ & $2(4.5 \%)$ & 7 \\
\hline Total & $25(100 \%)$ & $69(100 \%)$ & $7(100 \%)$ & $44(100 \%)$ & 145 \\
\hline
\end{tabular}

TABLE 6. Maintenance of breastfeeding continuity in relation to the existing problems associated with feeding

\begin{tabular}{|c|c|c|c|c|c|c|}
\hline \multirow{3}{*}{ Problems with feeding } & \multicolumn{6}{|c|}{ Maintenance of feeding continuity } \\
\hline & \multicolumn{2}{|c|}{ yes, still exclusive breastfeeding } & \multicolumn{2}{|c|}{$\begin{array}{l}\text { partly, I had to introduce } \\
\text { milk formula }\end{array}$} & \multicolumn{2}{|c|}{$\begin{array}{l}\text { no, since there is a problem } \\
\text { my baby is fed with milk formula }\end{array}$} \\
\hline & $\mathrm{n}$ & $\%$ & $\mathrm{n}$ & $\%$ & $\mathrm{n}$ & $\%$ \\
\hline No food & 3 & 3.5 & 13 & 8.4 & 3 & 15 \\
\hline Little food & 7 & 8.1 & 30 & 19.5 & 3 & 15 \\
\hline Breast Fullness & 10 & 11.6 & 6 & 3.9 & 1 & 5 \\
\hline The child did not gain weight & 5 & 5.8 & 14 & 9.1 & 1 & 5 \\
\hline The impression that the baby is hungry & 9 & 10.5 & 21 & 13.6 & 3 & 15 \\
\hline Health problems & 0 & 0 & 0 & 0 & 1 & 5 \\
\hline Complementary feeding of the baby & 10 & 11.6 & 44 & 28.6 & 5 & 25 \\
\hline The infant did not want to suck & 4 & 4.7 & 10 & 6.5 & 1 & 5 \\
\hline Flat, concave nipples & 7 & 8.1 & 10 & 6.5 & 2 & 10 \\
\hline Total & 86 & 100.0 & 154 & 100.0 & 20 & 100 \\
\hline \multicolumn{2}{|c|}{$\begin{array}{l}\text { The result of the } x^{2} \text { test, investigating the impact of lack of } \\
\text { breast milk on continuity of feeding }\end{array}$} & \multicolumn{2}{|c|}{$x^{2}$} & df & \multicolumn{2}{|c|}{$\mathrm{p}$} \\
\hline \multicolumn{2}{|c|}{$X^{2} N W$} & \multicolumn{2}{|c|}{11.93379} & 2 & \multicolumn{2}{|c|}{0.00256} \\
\hline \multicolumn{2}{|c|}{$\begin{array}{l}\text { The result of } x^{2} \text { test investigating the impact of small } \\
\text { amounts of breast milk on continuity of feeding }\end{array}$} & \multicolumn{2}{|c|}{$x^{2}$} & df & \multicolumn{2}{|c|}{$\mathrm{p}$} \\
\hline \multicolumn{2}{|c|}{$\mathrm{X}^{2} \mathrm{NW}$} & \multicolumn{2}{|c|}{22.41377} & 2 & \multicolumn{2}{|c|}{0.00001} \\
\hline \multicolumn{2}{|c|}{$\begin{array}{l}\text { The result of } x^{2} \text { test investigating the impact of maternal impres- } \\
\text { sion that the infant is hungry on maintenance feeding continuity }\end{array}$} & \multicolumn{2}{|c|}{$x^{2}$} & df & \multicolumn{2}{|c|}{$\mathrm{p}$} \\
\hline $\mathrm{X}^{2} \mathrm{NW}$ & & \multicolumn{2}{|c|}{8.196915} & 2 & \multicolumn{2}{|c|}{0.01660} \\
\hline
\end{tabular}


TABLE 7. Maintenance of breastfeeding continuity in relation to feeding difficulties

\begin{tabular}{|c|c|c|c|c|c|c|}
\hline \multirow{3}{*}{ Feeding difficulties } & \multicolumn{6}{|c|}{ Maintenance of feeding continuity } \\
\hline & \multicolumn{2}{|c|}{$\begin{array}{l}\text { yes, I still breastfeed } \\
\text { exclusively }\end{array}$} & \multicolumn{2}{|c|}{$\begin{array}{l}\text { partly, I had to introduce } \\
\text { milk formula }\end{array}$} & \multicolumn{2}{|c|}{$\begin{array}{l}\text { no, since there is a problem } \\
\text { my baby is fed milk formula }\end{array}$} \\
\hline & n & $\%$ & $\mathbf{n}$ & $\%$ & $\mathbf{n}$ & $\%$ \\
\hline Correct attachment & 23 & 14.7 & 34 & 22.5 & 2 & 14.3 \\
\hline Nipple soreness & 43 & 27.4 & 38 & 25.2 & 2 & 14.3 \\
\hline Assessment of how much an infant has eaten & 41 & 26.1 & 37 & 24.5 & 3 & 21.5 \\
\hline A large amount of time spent at the breast & 13 & 8.3 & 13 & 8.6 & 2 & 14.3 \\
\hline Continuous availability & 5 & 3.2 & 6 & 4 & 1 & 7.1 \\
\hline Proper diet & 6 & 3.8 & 5 & 3.3 & 1 & 7.1 \\
\hline Exhaustion & 20 & 12.7 & 14 & 9.3 & 1 & 7.1 \\
\hline Not applicable & 4 & 2.5 & 2 & 1.3 & 2 & 14.3 \\
\hline Others & 2 & 1.3 & 2 & 1.3 & 0 & 0 \\
\hline
\end{tabular}

TABLE 8. Maintenance of feeding continuity in relation to the support received

\begin{tabular}{|c|c|c|c|c|c|c|}
\hline \multirow[b]{2}{*}{ Received support } & \multicolumn{6}{|c|}{ Maintenance of feeding continuity } \\
\hline & \multicolumn{2}{|c|}{$\begin{array}{l}\text { yes, I still exclusive } \\
\text { breastfeed }\end{array}$} & \multicolumn{2}{|c|}{$\begin{array}{l}\text { partly, I had to introduce } \\
\text { milk formula }\end{array}$} & \multicolumn{2}{|c|}{$\begin{array}{l}\text { no, since there is a problem } \\
\text { my baby is fed milk formula }\end{array}$} \\
\hline Yes, I received a lot of help & 45 & 64.4 & 41 & 60.3 & 5 & 71.4 \\
\hline Yes, I received some help, but insufficient & 5 & 7.1 & 13 & 19.1 & 2 & 28.6 \\
\hline $\begin{array}{l}\text { No, I did not receive any help, even though I asked } \\
\text { for it }\end{array}$ & 1 & 1.4 & 2 & 2.9 & 0 & 0.0 \\
\hline No, I did not need help & 19 & 27.1 & 12 & 17.7 & 0 & 0.0 \\
\hline Total & 70 & 100.0 & 68 & 100.0 & 7 & 100.0 \\
\hline
\end{tabular}

TABLE 9. Maintenance of feeding continuity in relation to the person who provided support

\begin{tabular}{|c|c|c|c|c|c|c|}
\hline \multirow[b]{2}{*}{ Supporting person } & \multicolumn{6}{|c|}{ Maintenance of feeding continuity } \\
\hline & \multicolumn{2}{|c|}{ yes, I still exclusive breastfeed } & \multicolumn{2}{|c|}{$\begin{array}{l}\text { partly, I had to introduce } \\
\text { milk formula }\end{array}$} & \multicolumn{2}{|c|}{$\begin{array}{l}\text { no, since there is a problem } \\
\text { my baby is fed milk formula }\end{array}$} \\
\hline Paediatrician & 7 & 8.3 & 10 & 11.8 & 0 & 0.0 \\
\hline Obstetrician & 5 & 6.0 & 5 & 5.9 & 0 & 0.0 \\
\hline Lactation consultant & 13 & 15.5 & 10 & 11.8 & 0 & 0.0 \\
\hline Midwife & 25 & 29.8 & 40 & 47.0 & 4 & 57.1 \\
\hline I did not get help & 6 & 7.1 & 11 & 12.9 & 1 & 14.3 \\
\hline I did not need help & 28 & 33.3 & 9 & 10.6 & 2 & 28.6 \\
\hline Total & 84 & 100.0 & 85 & 100.0 & 7 & 100.0 \\
\hline
\end{tabular}

Competent support with problems related to breastfeeding should be the standard in maternity wards. However, analyzing the continuity of feeding, it was received by only $60.3-71.4 \%$ women in childbirth. Most of the patients who received support breastfed their infants exclusively (64.4\%). Slightly fewer were patients who, despite the support received, had to partially introduce milk formula (60.3\%). As many as $71.4 \%$ of women who received support did not breastfeed (Tab. 8). No statistical significance was noted.

The best prepared health care workers to assist in lactation problems are: a midwife/a lactation consultant, neonatologist and obstetrician-gynaecologist. As shown in Table 9, patients with the most common lactation problems could count on midwives (29.8-57.1\%), lactation consultants (11.8-15.5\%) and neonatologists (8.3-11.8\%). Midwives had a significant impact on continuity of feeding $(p=0.02)$ - Table 9 .

\section{DISCUSSION}

According to the World Health Organization recommendations, infants should be breastfed exclusively. Partially breastfed infants, in addition to breast milk, are given other types of milk or liquids. The results of this study indicate that $64.1 \%$ of newborns received complementary foods. The most common method was bottle feeding. The research of Małańczuk et al., 
also shows a high rate $(67.4 \%)$ of infants who received complementary foods [2]. However, in the studies by Zgórecka et al., in Obstetrics and Neonatal Departments complementary foods were given to $47.7 \%$ of infants [3]. Complementary feeding with modified milk formula is associated with a high risk of shortening exclusive breastfeeding, as well as the total time of breast-feeding [4]. In our study, only $20.4 \%$ of women who gave complementary foods to their newborns sustained exclusive breastfeeding.

The most common reason for failure in maintaining the continuity of breastfeeding was lactation problems. The results of this study indicate that $58.0 \%$ of respondents complained of painful nipples, insufficient milk supply (27.3\%), or lack thereof (13.3\%). Correct attachment of a newborn at the breast also caused difficulty (41.3\%), as well as assessment of how much the infant ate (56.6\%). Mostly, the above problems made the women sustain breastfeeding only partially. The research conducted by Gebuza et al. shows that $14.3 \%$ of women suffered from painful nipple damage, whereas $40 \%$ women giving birth for the first time and $18.8 \%$ more than once had problems with lactation [5]. However, in Józefów et al. studies, primiparas, after giving birth vaginally, complained about the lack of or insufficient lactation (30\%), as well as nipple pain (25\%). Painful nipples appearing in the early postpartum period are treated as physiological, and according to Nehring-Gugulska et al., appear in 36-90\% of women in childbirth [6]. Based on current research, it is concluded that it is of the utmost importance in the course of lactation to provide birth professionals' assistance in these problems after delivery [7]. Also, the results of the conducted analysis show how important medical staff aid and support are in solving lactation problems and difficulties. Our study indicates that in $98.7 \%$ of the surveyed patients the help and support of medical staff in breastfeeding during the hospital stay was definitely needed. Such aid was received by $75.8 \%$ of the women surveyed. Most women received support and assistance from midwives (47.5\%), and to a lesser extent from obstetricians (7.0\%) and paediatricians (11.9\%). It should be considered why, in $11.9 \%$ of the women surveyed, no one provided assistance in solving their problems. The research of Małańczuk et al. indicates that $86.2 \%$ of women received support from midwives, $8.5 \%$ from neonatologists, and $4.3 \%$ from obstetricians. No assistance was obtained by $12.8 \%$ of mothers [2]. The Ulman-Włodarz et al. study found that the majority of women surveyed (86.25\%) could count on the assistance of medical personnel, particularly midwives [8].

Many authors emphasize the negative impact of caesarean delivery on lactation. Prior, relying on research conducted in 53 centres, shows that the proportion of women after caesarean delivery with normal lactation is lower, and shows that it is particularly disadvantageous to perform a caesarean section before systolic function [9]. The cause of delayed lactation may also be a smaller release of oxy tocin during caesarean sections, particularly elective ones, and childbirth before term, when production of this hormone is still low [10]. Also significant is the fact that the newborns of women giving birth by caesarean section are often separated from their mothers. The 'skin to skin' contact and early attachment of the baby at the breast are impossible, then which can delay the natural triggering of lactation [11]. The results of the analysis indicate that most women after caesarean delivery partially breastfed their infants (57.9\%). Complementary foods were given to then more often.

\section{CONCLUSIONS}

1. Some hospital practices, such as suctioning the airway, short 'skin to skin' contact after caesarean delivery, and complementary feeding of a newborn baby with a bottle had a negative impact on maintaining lactation.

2. Complementarily feeding an infant with a bottle was a frequent hospital practice. As the procedure has an adverse impact on lactation, breastfeeding should be replaced by complementary feeding in an alternative way only in justified cases.

3. Most of the patients who obtained support during lactation were breastfeeding exclusively. Competent assistance in initiating and maintaining lactation is the responsibility of the medical personnel, and thus there is a necessity for their permanent development, and a constant need to modify hospital practices to ones that affect lactation favourably.

\section{REFERENCES}

1. Nehring-Gugulska M. Standardy postępowania w laktacji. Standardy Med 2005;2(5):1939.

2. Małańczuk D, Woźniak P, Gulczyńska E, Rudnicka B, Wrońska B, Krasomski G. Ocena wdrażania standardu opieki okołoporodowej w aspekcie „10 kroków do udanego karmienia piersią”. Gin Pol Med Project 2014; 2(32):43-53.

3. Zgórecka E, Stolarczyk A, Socha P, Piotrowska-Jastrzębska J, Socha J. Rodzaje mleka i przetwory mleczne w diecie niemowląt z wybranych ośrodków Polski Centralnej i Wschodniej. Pediatr Pol 2007;82(9):690-749.

4. Woś H, Gawęda A. Przyczyny rezygnacji z karmienia naturalnego dzieci z terenu Górnego Śląska. Nowa Pediat 2007;3:54-9.

5. Gebuza G, Kaźmierczak M, Gierszewska M, Michalska E. Problemy kobiet w połogu i ich przyczyny. Perinatol Neonatol Ginek 2010;7(5/6):290-5.

6. Nehring-Gugulska M, Żukowska-Rubik M, Pietkiewicz A. Karmienie piersią w teorii i praktyce. Warszawa: Wyd. Medycyna Praktyczna; 2012.

7. Kiełbratowska B, Preis K. Opieka położnicza po cięciu cesarskim wspierająca karmienie piersią. Ginek Położ 2007;2(2):56.

8. Ulman-Włodarz I, Mucha A, Kwiatkowska E. Karmienie naturalne po przebytym porodzie rodzinnym. Klin Perin Ginek 2004:74-8.

9. Prior E, Santhakumaran S, Gale C, Philipps LH, Modi N, Hyde MJ. 13 Breastfeeding after cesarean delivery: a systematic review and meta-analysis of world literature. Am J Clin Nutr 2012;24(3):293-302.

10. Hill PD, Aldag JC, Demitras H, Naeem V, Parker NP, Zinaman MJ, et al. Association of serum prolactin and oxytocin with milk production in mothers of preterm and term infants. Biol Res Nurs 2009;10(4): 340-9.

11. Elliot-Carter N, Harper J. Keeping mothers and newborns together after cesarean: how one hospital made the change. Nurs Womens Health 2012;16(4):290-5. 